\begin{tabular}{ccc}
\hline International Journal of Engineering \& Technology, $7(4.38)(2018) 122-124$ \\
SPC \\
Website www.sciencepubco.com/index.php/IJET \\
Research paper
\end{tabular}

\title{
Analysis of Genetic Diversity in three Kazakh Sheep using 12 Microsatellites
}

\author{
Kairat Dossybayev 1,2,3,*, Aizhan Mussayeva', Bakytzhan Bekmanov 1,3, Beibit Kulataev \\ ${ }^{1}$ Laboratory of Animal Genetics and Cytogenetics, Institute of General Genetics and Cytology, Almaty, Kazakhstan \\ ${ }^{2}$ Faculty of Bioresources and Technology, Kazakh National Agrarian University, 8 Abai avenue, Medeu district, Almaty, 050010, \\ Kazakhstan \\ ${ }^{3}$ Faculty of Biology and Biotechnology, Al-Farabi Kazakh National University, 71 al-Farabi avenue, Almaty, 050040, Kazakhstan \\ *Corresponding author E-mail: dossybayev.k@mail.ru
}

\begin{abstract}
The genetic structure of three Kazakh sheep breeds was examined by using 12 microsatellite loci. A total of 144 alleles were detected from the 12 STR loci, with a mean value of 12.0. The highest allele diversity was found at the locus CSRD247 (16 alleles). PIC value showed that all studied STR markers are more informative and appropriate for genetic analysis of three Kazakh sheep populations. Beside of INRA006, all markers had high level of genetic variability. As Fixation index shows, the excess of the heterozygosity was observed only in loci MAF065. Obtained number of private alleles in Edilbai, Kazakh Arkhar Merino and Kazakh Fine-wool sheep were 25, 17 and 15 respectively. Genetic diversity was higher in Edilbai population than in other two populations. The genetic variability was lower in Kazakh Arkhar Merino sheep than in the Edilbai and Kazakh Fine-wool sheep breeds. The genetic distance was the largest between Edilbai and Kazakh Arkhar Merinos. Also, the moderate differentiation was observed between Edilbai and Kazakh Arkhar Merinos.
\end{abstract}

Keywords: Edilbai, Kazakh Fine-Wool, Kazakh Arkhar Merino, Microsatellites, Gene Diversity..

\section{Introduction}

Sheep breeding is one of the leading animal agricultural sectors in Kazakhstan due to its vast expanses and favorable climatic conditions for breeding of these animals, and also, due to the high productivity of this industry. Sheep are grown not only to obtain meat, but also as a source of wool, sheep skin, lamb, fat, milk, and a valuable organic fertilizer-manure. Edilbai, Kazakh fine-wool and Kazakh Arkhar Merinos are special sheep breeds bred in Kazakhstan [1].

Edilbai sheep breed is a representative of the national selection, which was carried out about 200 years ago. In the breeding process, sheep, selected for breeding, were the most adapted to the natural and climatic conditions of nomadic sheep breeding. Edilbai sheep breed is tolerable to the summer drought and winter cold and easily produce numerous offspring. In addition, according to the morphphysiological composition, sheep have the ability to easily gain fat on a sparse, thinned pasture fodder [2].

Kazakh Arkhar Merinos is a breed of fine-wooled sheep of meatwoolly direction. The breed was created on the basis of the interspecific hybridization of wild sheep argali with uterine fins: Novo-Caucasian merinos, prekos and rambulie. This sheep breed has a sturdy constitution, with a strong, well developed skeleton which allows them to graze on the mountainous pastures, usually inaccessible for other sheep breeds [3-4].

Kazakh fine-wool sheep breed is a breed of meat-woolly direction. It is derived by crossing Kazakh sheep with prekos sheep breed. Due to the careful selection and wide application of linear breeding, the Kazakh fine-wool breed combined the valuable features of local sheep breed -large size, quality meat, endurance and ability to year-round pasture maintenance [2].

Unfortunately, the genetic diversity of the breeds mentioned above was not described in details. These days, the research onthe genetic diversity of animals is widely performed with the help of microsatellite markers and many research works were carried out to describe genetic diversity of sheep [5-9].

Microsatellite DNA markers can serve as a tool for genetic identification of breeds, types, lines of agricultural animals, for determination of the genetic structure and assessing genetic distances between groups of animals, assessing the magnitude and direction of the gene flow between populations and as a determination of the effective population size of endangered and small populations [10-12].

Despite of the emergence of the new methods of genotyping, microsatellite markers play an important role in the genetic testing of different breedsof agricultural animal populations due to such important advantages as uniform distribution in the genome, great allelic diversity, high information content, Mendelian inheritance and ease of automation of determination [13-14].

\section{Materials and methods}

The blood samples were taken from 45 unrelated individuals of the 3 sheep breeds, where 15 animals of every breed were chosen randomly. Genomic DNA was extracted from white blood cells using Gene JET Genomic DNA Purification Kit. In this paper, 12 microsatellites recommended by ISAG (Table 1) were used to study genetic diversity of three Kazakh sheep breeds. The polymerase chain reaction was performed in a thermal cycler 
(Bio-Rad). The 12 microsatellites were previously tested by PCR analysis and screened for the successfully amplified STR markers. The PCR reaction volume, conditions and grouping to multiplexes have been adjusted according to Baumung R. 2006 [15]. PCR products were attached at ABI PRISM 310 Genetic Analyzer (Applied Biosystems). For the interpretation of the allele variants and fragment sizes, there was used GeneMapper software. Statistical processing of data was carried out by software GenAlex 6.5 and Excel microsatellite Toolkit (version 3.1) [16-17].

\section{Discussion}

A total of 144 alleles were indentified from the 12 STR loci of the three sheep breeds. The number of identified alleles per locus varied from 7 in D5S2 to 16 in CSRD247, with a mean of 12.0. In the analysis of survey findings, the highest and the lowest effective number of alleles have been found in marker INRAO05 (6.9) and McM042 (3.1) respectively, and the alleles effective number mean was 4.592 for the 12 markers. The maximum and minimum observed and expected heterozygosity ranged from $(\mathrm{Ho})$ 0.888 and $(\mathrm{He}) 0.891$ to $(\mathrm{Ho}) 0.466$ and $(\mathrm{He}) 0.718$ accordingly. The mean value of these two parameters were 0.720 and 0.811 . Calculating polymorphic information content value $(P I C)$ showed that the greatest $P I C$ value was 0.870 , while the smallest was 0.667 , with a mean of 0.777 . Fixation index was between 0.375 and -0.096 . Total number of alleles, private alleles, mean number of alleles and effective number of alleles were larger in Edilbai sheep than the Kazakh Arkhar Merino and Kazakh Finewool. Observed heterozygosity ranged from $0.678 \pm 0.051$ to $0.744 \pm 0.048$ among the breeds. The highest expected heterozygosity was observed in Edilbai, whereas the lowest value was obtained from Kazakh Arkhar Merino. Moreover, Edilbai breed had higher fixation index (Table 1).

Table 1: Genetic diversity of Kazakh sheep breeds based on the 12 microsatellites ( $\mathrm{Na}$ - number of alleles, $\mathrm{Ne}$ - effective number of alleles, $\mathrm{Ho}$ - observed heterozygosity, He - expected heterozygosity, $P I C$ - polymorphic information content, $F$ - fixation index)

\begin{tabular}{|c|c|c|c|c|c|c|}
\hline Locus & $N a$ & $N e$ & $H o$ & $H e$ & $P I C$ & $F$ \\
\hline CSRD247 & 16 & 5.685 & 0.666 & 0.869 & 0.844 & 0.233 \\
\hline D5S2 & 7 & 3.536 & 0.688 & 0.753 & 0.705 & 0.086 \\
\hline INRA005 & 13 & 6.938 & 0.866 & 0.885 & 0.863 & 0.021 \\
\hline INRA006 & 10 & 3.378 & 0.466 & 0.746 & 0.698 & 0.375 \\
\hline INRA023 & 14 & 5.767 & 0.777 & 0.891 & 0.870 & 0.127 \\
\hline INRA63 & 13 & 5.481 & 0.844 & 0.863 & 0.840 & 0.022 \\
\hline INRA172 & 12 & 3.495 & 0.600 & 0.718 & 0.689 & 0.164 \\
\hline MAF065 & 12 & 4.176 & 0.866 & 0.790 & 0.752 & -0.096 \\
\hline MAF214 & 12 & 3.194 & 0.600 & 0.765 & 0.720 & 0.215 \\
\hline McM042 & 11 & 3.131 & 0.666 & 0.719 & 0.667 & 0.073 \\
\hline McM527 & 12 & 4.574 & 0.711 & 0.840 & 0.810 & 0.153 \\
\hline OarFCB20 & 12 & 5.751 & 0.888 & 0.889 & 0.867 & 0.001 \\
\hline Mean & 12.0 & 4.592 & 0.720 & 0.811 & 0.777 & 0.112 \\
\hline
\end{tabular}

\section{Discussion}

In order to measure the genetic diversity and variability of the three sheep breeds were used 12 microsatellites, located on the different chromosomes of the sheep and differed in their base pairsize. From literature sources it is known that the information about genetic diversity is useful for farmers to improve their breeds and adapt livestock populations to the changing environment. The highest genetic diversity was detected at the marker CSRD247 with 16 alleles, this value being higher than the 13 alleles found in four populations of Nguni sheep (N.W. Kunene et al.) [18]. However, INRAO05 marker showed high level of effectiveness. All 12 loci studied were highly informative, with an overall mean of PIC value 0.77 and also all markers had the PIC value higher than 0.5 [19]. In this study, the $P I C$ value was higher than the value reported by J.Y. Bai [20]. Depending on the high value of $P I C$, these 12 polymorphic microsatellite markers are suitable for studies of the genetic diversity, structure and mating system of Kazakh three sheep breeds. In addition, there were identified several STR markers with high levels of genetic diversity: INRA005, INRA63 and OarFCB20. Fixation index results showed that all of the markers were observed under random mating, with the exception of MAF065. After estimating the number of alleles in the populations separately, we found that the Edilbai sheep had the highest genetic diversity (100 alleles). The Kazakh Finewool's number of alleles (95 alleles) was higher than that of the Kazakh Arkhar Merino ( 85 alleles). The examined sheep populations differed from each other by the private alleles. A total of 57 private alleles were detected for the three sheep breeds. 25 out of 57 private alleles were observed in Edilbai sheep whereas Kazakh Arkhar Merino and Kazakh Fine-wool sheep had 17 and 15 private alleles accordingly. The most common private alleles were found in the following loci: allele 196 at the locus INRA023 of the Kazakh Arkhar Merino breed (frequency of occurrence - 0.167), allele 130 at the locus INRAOO6 of the Kazakh fine-wool sheep breed (frequency of occurrence -0.267 ), allele 162 in the INRA172 locus of the Edlbai breed (frequency of occurrence -0.167 ). The frequencyof the remaining private alleles was less than 0.1 . These private alleles were proven to be essential for the characterization of the investigated sheep breeds [21-24]. Comparing genetic diversity parameter among the populations, the greatest mean number of alleles $8.333 \pm 0644$ was at the Edilbai breed, which is higher than the results of E. Sh. Seidani et al. (2009) and A. Ferrando (2014) [25-26]. Therefore, it can be concluded that the selection of superior animals is taking place in the population of Edilbai sheep breed. Furthermore, the effective number of alleles was calculated among the breeds, where $\mathrm{Ne}$ value ranged from $3.902 \pm 0.477$ to $4.975 \pm 0.461$. The obtained indicators were similar to the result of S.B.S. Gaouaret al. (2016) and greater than the values reported by X. C. Zeng et al. (2010) [27-28]. In order to compare the genetic variability of the three sheep breeds, the observed and expected heterozygosity was estimated for each pair of populations (Table 2).

Table 2: Population-genetic parameters between the studied sheep breeds. (TNA - total number of alleles, $P a$ - private alleles, $M N A$ - mean number of alleles, $\mathrm{Ne}$ - effective number of alleles, $\mathrm{Ho}$ - observed heterozygosity, $\mathrm{He}$ - expected heterozygosity, $\mathrm{F}$ - fixation index)

\begin{tabular}{|c|c|c|c|c|c|c|c|}
\hline \begin{tabular}{|l} 
Populatio \\
$\mathrm{n}$
\end{tabular} & \begin{tabular}{|c|}
$T N$ \\
$A$ \\
\end{tabular} & $\begin{array}{l}P \\
a\end{array}$ & $M N A$ & $\mathrm{Ne}$ & Ho & $\mathrm{He}$ & $F$ \\
\hline $\begin{array}{l}\text { Kazakh } \\
\text { Arkhar } \\
\text { Merino }\end{array}$ & 85 & 17 & $\begin{array}{c}7,083 \pm 0.63 \\
3\end{array}$ & $\begin{array}{c}3.902 \pm 0.47 \\
7\end{array}$ & $\begin{array}{c}0,678 \pm 0,05 \\
1\end{array}$ & $\begin{array}{c}0,702 \pm 0,03 \\
3\end{array}$ & $\begin{array}{c}0.03 \\
5\end{array}$ \\
\hline \begin{tabular}{|l|} 
Kazakh \\
Finewool
\end{tabular} & 95 & 15 & $\begin{array}{c}7.917 \pm 0.55 \\
7\end{array}$ & $\begin{array}{c}4.900 \pm 0.53 \\
8\end{array}$ & $\begin{array}{c}0,744 \pm 0,04 \\
8\end{array}$ & $\begin{array}{c}0,770 \pm 0,02 \\
2\end{array}$ & $\begin{array}{c}0.03 \\
6\end{array}$ \\
\hline Edilbai & 100 & 25 & $\begin{array}{c}8.333 \pm 064 \\
4\end{array}$ & $\begin{array}{c}4.975 \pm 0.46 \\
1\end{array}$ & $\begin{array}{c}0,739 \pm 0,05 \\
2\end{array}$ & $\begin{array}{c}0,777 \pm 0,02 \\
3\end{array}$ & $\begin{array}{c}0.05 \\
8\end{array}$ \\
\hline Total & 280 & & \begin{tabular}{|c}
$7,778 \pm 0,35$ \\
4 \\
\end{tabular} & $\begin{array}{c}4,592 \pm 0,28 \\
9\end{array}$ & $\begin{array}{c}0,720 \pm 0,02 \\
9\end{array}$ & $\begin{array}{c}0,750 \pm 0,01 \\
6 \\
\end{array}$ & $\begin{array}{c}0.04 \\
3 \\
\end{array}$ \\
\hline
\end{tabular}

The highest average level of observed heterozygosity was found in Kazakh Fine-wool population $(0.744 \pm 0.048)$, which did not differentiate a lot from that of Edilbai $(0.739 \pm 0.052)$, although, these values were much higher than those for the Kazakh Arkhar Merinos breed $(0.678 \pm 0.051)$. The expected heterozygosity ranged from $0.777 \pm 0.023$ to $0.702 \pm 0.033$ among the breeds. Populationgenetic studies showed that the total observed and expected heterozygosity were $0.720 \pm 0.029$ and $0.750 \pm 0.016$ respectively. Comparable genetic variability has been reported by E. GuangXin et al. (2016) and R. Ocampoet al. (2015) in 14 native Chinese sheep and Colombian sheep breeds [29-30]. Among the populations, Fixation index $(F)$ varied from 0.035 for Kazakh Arkhar Merinos to 0.058 for Edilbai $(0<F<1)$ [31]. As a result, Fixation index revealed the random-mating events in all populations. Evaluation of the genetic distance in populations showed that the greatest values observed were between Kazakh Arkhar Merinos and Edilbai (0.469), however, the smallest genetic distance was between Kazakh Arkhar Merinos and Kazakh Finewool (0.259). This could be explained bythe direction of 
productivity, Kazakh Arkhar Merinos and Kazakh Fine-wool have been fine wool direction sheep breeds and Edilbai is coarse wool sheep. $F_{s t}$ values varied from 0.040 for Kazakh Fine-wool to 0.063 for

Edilbai

(Table 3). Obtained genetic divergence indicated that the moderate differentiation was observed between Edilbai and Kazakh Arkhar Merinos $\left(F_{s t}>0.05\right)$ [32]. A little genetic differentiation was found between Fine-wool and Kazakh Arkhar Merinos, as well as between Edilbai and Kazakh Finewool. The $F_{s t}$ values were lower between Kazakh Fine-wool and Kazakh Arkhar Merinos than those between Edilbai and Kazakh Finewool (Table 3).

Table 3: Genetic distance (above diagonal) and differentiation (below diagonal) of three sheep populations

\begin{tabular}{|l|c|c|c|}
\hline & AK & KT & ED \\
\hline AK & $\mathbf{0 . 0 0 0}$ & 0.259 & 0.469 \\
\hline KT & 0.040 & $\mathbf{0 . 0 0 0}$ & 0.401 \\
\hline ED & 0.063 & 0.046 & $\mathbf{0 . 0 0 0}$ \\
\hline
\end{tabular}

\section{Conclusion}

To study the genetic structure of three sheep breeds, there were selected 12 microsatellite loci recommended by ISAG. Due to the fact that the number of alleles, the PIC index and the level of heterozygotes were high, all studied 12 microsatellite markers were highly effective for analyzing the genetic structure and variability of three Kazakh sheep breeds. According to the results of the study, these sheep breeds differ from each other not only in terms of morphological features and productivity, but also in the number of alleles, frequency of their occurrence and in the detected private alleles. In addition, the level of genetic differentiation between the Edilbay and the Kazakh Arhar Merinos was higher compared to the same index between the Kazakh Arkhar Merinos and Kazakh fine wool breeds.

\section{Acknowledgement}

This research was supported by the World Bank and the Ministry of Education and Science of the Republic of Kazakhstan (Grant No: 541).

\section{References}

[1] Dossybayev K, Mussayeva A, Orazymbetova Z, Tulekei M, Bekmanov B, Makhatov B (2018), Characteristics of Kazakh sheep breeds by Microsatellite DNA loci. Supplement: 43rd FEBS Congress, Biochemistry Forever (July 7-12, 2018), Volume 8, Issue S1, Prague, Czech Republic, pp: 1-510.

[2] Dmitriev NG and Ernst LK (1989), Animal genetic resources of the USSR. Food and Agriculture Organization of the United Nations Rome.

[3] Chernyshova E (2018), Kazakhskiy arkharomerinos, www.agroxxi. ru/wiki-animal/ovcy/tonkorunnye-porody-ovec/mjaso-sherstnyeovcy/kazahskii-arharomerinos.html.

[4] Bekmanov BO, Mussayeva AS, Amirgalieva AS, Orasimbetova ZS, Dossybaev KZh, Amanbaeva UI, Tulekei M, Zhapbasov R, Zhomartov AM, Moldasanov KZh (2016), Characteristics of the sheep breed Kazakh arharomerinos using ISSR-markers. News of the National Academy of Sciences of the Republic of Kazakhstan, Volume 6, Number 36, pp: 5-10.

[5] Vajed Ebrahimi MT et al. (2017), Using microsatellite markers to analyze genetic diversity in 14 sheep types in Iran. Arch. Anim. Breed., 60, pp: $183-189$.

[6] Farid A et al. (2000), Genetic analysis of ten sheep breeds using microsatellite markers. Canadian Journal of Animal Science, 80, pp: 9 17.

[7] Mahmoud et al. (2017), Genetic diversity among Sawakni, Berberi and Najdi sheep breeds in Saudi Arabia using microsatellites markers. Afr. J. Biotechnol, Vol. 16(4), pp: 171-178.

[8] Mukhongo et al. (2014), Genetic Diversity and Population Structure of theIndigenous Sheep in Kenya Based on MicrosatelliteAnalysis: Implications for their Conservation. J. Livestock Sci., 5, pp: 65-78.
[9] Ravimurugan T (2017), Genetic Diversity Analysis of Kilakarsal Sheep by Microsatellite Markers. Int. J. Curr. Microbiol. App. Sci., 6(9), pp: 573-577.

[10] Jones AG, Small CM, Paczolt KA, Ratterman NL (2010), A practical guide to methods of parentage analysis. Molecular Ecology Resources, 10, pp: 6-30.

[11] Radko A, Rychlik T (2010), Evaluating the usefulness of polymorphism of 7 microsatellite DNA markers for genetic diversity studies of sheep Ann. Anim. Sci., Vol. 10, No. 4, pp: 373-378.

[12] Abad-Zavaleta et al. (2011), Genetic diversity analysis of two desert bighorn sheep (Ovis Canadensis mexicana) population in Mexico. Tropical and Subtropical Agroecosystems, 14, pp: 171-178.

[13] Tautz D, Renz M (1984), Simple sequences are ubiquitous repetitive components of eukaryotic genomes. Nucleic Acids Research, No 12, pp: 4127-4138.

[14] Putman AI, Carbone I (2014), Challenges in analysis and interpretation of microsatellite data for population genetic studies. Ecology Evolution, No 4 (22), pp. 4399-4428

[15] Baumung R et al. (2006), Genetic characterisation and breed assignment in Austrian sheep breeds using microsatellite marker information. J. Anim. Breed. Genet.265-271.

[16] Baumung R, Cubric-Curik V, Schwend K, Achmann R, Sölkner J (2006), Genetic characterisation and breed assignment in Austrian sheep breeds using microsatellite marker information. J Anim Breed Genet, Aug 123(4), pp: 265-271.

[17] Peakall R, Smouse P (2012), GenAlEx 6.5: genetic analysis in excel. Population genetic software for teaching and research - an update. Bioinformatics, 28, pp: 2537-2539.

[18] Park SDE (2001), The Excel microsatellite toolkit (version 3.1). Anima Genomics Laboratory, University College; Dublin, Ireland.

[19] Kunene NW et al. (2014), Genetic Diversity in Four Populations of Nguni (Zulu) Sheep Assessed by Microsatellite Analysis. Italian Journal of Animal Science, volume 13:3083, pp: 76-82.

[20] Botstein D, White RL, Skolnick M, Davis RW (1980), Construction of a genetic linkage map in man using restriction fragment length polymorphisms. Am J Hum Genet, May, 32(3), pp: 314-331.

[21] Jun Yan Bai et al. (2015), Polymorphism analysis of three Chinese indigenous sheep breeds by microsatellite markers. Indian Journal Of Animal Research, Volume 49, Issue 5, pp: 585-590.

[22] Szpiech ZA, Jakobsson M, Rosenberg NA (2008), ADZE: a rarefaction approachfor counting alleles private to combinations of populations. Bioinformatics, 24, pp: 2498-2504.

[23] Parker KM, Sheffer RJ, Hedrick PW (1999), Molecular variation and evolutionarily significant units in the endangered Gila topminnow. Conservation Biology, 13, pp: 108-116.

[24] Kalinowski ST (2004), Counting alleles with rarefaction: private alleles and hierarchical sampling designs. Conservation Genetics, 5, pp: 539543.

[25] Schroeder KB, Schurr TG, Long JC, Rosenberg NA, Crawford MH, Tarskaia LA, Osipova LP, Zhadanov SI, Smith DG (2007), A private allele ubiquitousin the Americas. Biology Letters, 3, pp: 218-223

[26] Seidani ES, Amirinia C, Lavaf A, Farasati C, Aminafshar M (2009) Genetic variation among different ecotypes of the Iranian Sanjabi sheep. J. Anim. Vet. Adv., 8(6), pp: 1173-1176.

[27] Ferrando A, Goyache F, Parés Casanova PM, Carrión C, Miró J, Jordanai Vidal J (2014), Genetic relationships between six eastern Pyrenean sheep breeds assessed using microsatellites Spanish. J. Agric. Res., 12(4), pp: 1029-1037.

[28] Gaouar SBS et al. (2016), Estimating population structure and genetic diversity offive Moroccan sheep breeds by microsatellite markers. Smal Ruminant Research, 144, pp: 23-27.

[29] Zeng XC et al. (2010), Genetic Diversity Measures of 8 Local Sheep Breeds in Northwest of China for Genetic Resource Conservation. Asian-Aust. J. Anim. Sci., 23(12), pp: 1552-1556.

[30] Guang-Xin E et al. (2016), Conservation genetics in Chinese sheep: diversity of fourteen indigenous sheep (Ovisaries) using microsatellite markers. Ecology and Evolution, 6(3), pp: 810-817.

[31] Ocampo R et al. (2016), Genetic diversity of Colombian sheep by microsatellite markers. Chilean journal of agricultural research, 76(1), pp: $40-47$.

[32] Fox CW, Roff DA, and Fairbairn DJ (2001), Evolutionary Ecology. Oxford University Press.

[33] Hartl D (1980), Principles of population genetics. Sunderland, MA: Sinauer Association Inc, Massachusset, USA, pp: 164-165. 